\title{
Rice Bran Oil Extraction as Trioxolane Raw Material
}

\section{Sri Handayani ${ }^{1}$, Sofa Fajriah ${ }^{2}$, Enjarlis ${ }^{1}$}

${ }^{1}$ Department of Chemical Engineering, Institut Teknologi Indonesia, Jl. Raya Puspitek Serpong, South Tangerang, Indonesia 15314

${ }^{2}$ Research Center for Chemistry, Indonesian Institute of Sciences, Kawasan PUSPIPTEK, Serpong, South Tangerang, Indonesia 15314

\begin{abstract}
Rice bran is a byproduct of rice processing which was generally used for animal feed. Rice bran oil could be used as raw material in the fields of pharmaceuticals, cosmetics, and food oil. The purpose of this research is to extract rice bran into oil as a raw material for Trioxolane using n-Hexane solvent and purify the oil by adsorption using bentonite. Trioxolent compounds were obtained from ozonated fatty acids. Variable extraction time 2, 3 and 4 hours and use of bentonite 2.5, 5 and 7.5 grams from $10 \mathrm{ml}$ of crude rice bran oil. The results obtained an oil yield of each variable extraction time 2, 3, and 4 hours respectively - the value is $8.4,10,11 \%$. The optimum operating conditions were obtained by extraction time of 4 hours and refining $75 \%$ bentonite. The characteristics of rice bran oil has a moisture content of $8 \%$, an acidic value of $67 \% \mathrm{mg} \mathrm{NaOH} / \mathrm{g}$ sample, a peroxide number of $21 \mathrm{mgrek} / \mathrm{g}$ sample, an iod number of $46 \mathrm{mgI} / \mathrm{g}$ sample and the results of fatty acid analysis using GCMS is $33.5 \%$ oleic acid, $24.8 \%$ Linoleic acid, 32.6\% Palmitic acid.
\end{abstract}

Keyword: Rice Bran, Extraction, Adsorption, Bentonite, n-hexane

\begin{abstract}
Abstrak. Dedak padi adalah hasil samping dari pengolahan padi yang umumnya digunakan untuk makanan ternak. Minyak dedak padi dapat digunakan sebagai bahan baku bidang farmasi, kosmetik, dan minyak pangan. Tujuan dari penelitian ini adalah mengekstraksi dedak padi menjadi minyak sebagai bahan baku Trioxolane menggunakan pelarut n-Hexane dan memurnikan minyak tersebut dengan cara adsorbsi menggunakan bentonit. Senyawa trioxolen diperoleh dari asam lemak yang diozonasi. Variabel waktu ekstraksi 2, 3 dan 4 jam dan pemakaian bentonit 2.5, 5 dan 7.5 gram dari $10 \mathrm{ml}$ minyak dedak padi kasar. Hasil penelitian didapatkan rendemen minyak dari masing-masing variabel waktu ekstraksi 2, 3, dan 4 jam berturut - turut nilainya adalah 8.4, 10, $11 \%$. Kondisi operasi yang terbaik diperoleh waktu ektraksi 4 jam dan untuk pemurnian digunakan bentonit 75\% dari minyak dedak padi kasar. Karakteristik minyak dedak padi tersebut memiliki kadar air $8 \%$, nilai bilangan asam sebesar $67 \% \mathrm{mg} \mathrm{NaOH} / \mathrm{g}$ sampel, bilangan peroksida $21 \mathrm{mgrek} / \mathrm{g}$ sample dan nilai bilangan Iod sebesar $46 \mathrm{mgI} / \mathrm{g}$ sampel, serta hasil analisa asam lemak menggunakkan GCMS adalah $33.5 \%$ asam oleat, $24.8 \%$ asam Linoleat dan $32.6 \%$ asam Palmitat.
\end{abstract}

Kata Kunci: Dedak Padi, Ekstraksi, Adsorpsi, Bentonit, n-hexane

Received 2 December 2019 | Revised 26 February 2020 | Accepted 27 February 2020

\footnotetext{
*Corresponding author at: Department of Chemical Engineering, Institut Teknologi Indonesia, Jl. Raya Puspitek

Serpong, South Tangerang, Indonesia

E-mail address: sri.handayani@iti.ac.id
} 


\section{Introduction}

Human Immuno deficiency Virus (HIV) is an infection of the immune system that can cause a decrease in immunity. Immune system deficiency disease caused by infection with the HIV virus is called Acquired Immuno Deficiency Syndrome (AIDS). There are two ways to prevent faster viral growth, these methods are ARV treatment and taking trioxolane medicine. Trioxolane is an active compound, produced from the ozonation process of unsaturated or alkene hydrocarbons through the Criegee mechanism. Sources of unsaturated hydrocarbons that are suitable as medicinal ingredients and are compatible with living tissue are vegetable oils containing $97-98 \%$ triglycerides with the composition of saturated and unsaturated fatty acids. Ozonated vegetable oil is called Ozonated Oil, containing dissolved ozone, trioxolane, peroxides, organic acids, and aldehydes. The quality of ozonated oil is determined by the number of trioxolane functional groups found in triglycerides. The number of trioxolane groups in ozonated oil is determined by the amount of unsaturated fatty acids in vegetable oils used as raw materials. Rice bran is a source of unsaturated hydrocarbons that has not been utilized optimally [1].

Indonesia is one of the biggest rice producers in the world. Rice production in Indonesia is around 83 million tons in 2018 (the Central Statistics Agency). Rice processing results obtained $70 \%$ rice, $20 \%$ husks, and $8-10 \%$ rice bran [2]. Rice bran is a by-product of rice production. Currently only used for animal feed, whereas rice bran contains $13.11 \%-17.19 \%$ protein, 2.52\% - 5.05\% fat, 67.58\% -72.74\% carbohydrates, 370.91 - 387 , 2 calories [3]. Besides rice bran contains a number of phenolic compounds, and is rich in dietary fiber, vitamins, and minerals [4].

The process of rice bran oil extraction is carried out through two stages, namely stabilization and solid-liquid extraction. Stabilization aims to destroy the lipase enzyme present in rice bran so that oil yield increases and free fatty acid levels decrease [5]. Stabilization can be done chemically or using heat. Heat stabilization causes the lipase enzyme in the bran to be deactivated at $100-120^{\circ} \mathrm{C}$ within a few minutes.

Several studies of rice bran extraction processes have been carried out using hexane, ethanol, and 2-propanol solvents in relation to yields and antioxidant content obtained. Suryati [6] extracted 50 grams of rice bran and used a $250 \mathrm{ml}$ n-hexane solvent, extraction time of 7 hours resulted in a yield of $13.5 \%$, FFA $2.88 \%$ and an oil density of $0.901 \mathrm{gr} / \mathrm{ml}$. Whereas Nasir [7] carried out a 15 minute stabilization temperature of $110^{\circ} \mathrm{C}$ and extraction for one hour of 50 grams rice bran and $350 \mathrm{ml}$ of solvent resulted in a yield of $18.34 \%$, an oil density $0.889 \mathrm{gr} / \mathrm{ml}$ and FFA $44.56 \%$. 
Purification of vegetable oils using adsorption methods can use zeolites [8], activated charcoal [9], and bentonite as adsorbents. Bentonite is clay which consists mainly of montmorillonite with minerals such as quartz, calcite, dolomite, feldspars, and other minerals. Montmorillonite is part of the smectite group with a general chemical composition (Mg, Ca) O. $\mathrm{Al}_{2} \mathrm{O}_{3} \cdot 5 \mathrm{SiO}_{2} \cdot \mathrm{nH}_{2} \mathrm{O}$.

\section{Research Method}

\subsection{Materials}

Rice bran (obtained from Tangerang Selatan, Banten, Indonesia), ethyl acetate, phenolpthlaein, sodium hydroxide, chloroform, bentonite, alcohol, wijs solution, starch (indicator), $\mathrm{Na}_{2} \mathrm{~S}_{2} \mathrm{O}_{3}$, acetic acid.

\subsection{Equipment}

Oven, analytical balance, a set of Extraction Tools (Soxhlet), Rotary Evaporator Installation Tools, a set of analysis tools extraction methods (erlenmeyer, statip, burette, beaker glass).

\subsection{Experimental Procedure}

Raw material (rice bran) is prepared 100 grams, stabilized by heating it in an oven for 15 minutes at $110^{\circ} \mathrm{C}$. The rice bran was extracted using n-hexane as much as $700 \mathrm{ml}$, and the time variation was 2, 3 and 4 hours. The crude rice bran oil (CRBO) that is formed is still mixed with n-hexane, then separated with a rotary evaporator at a temperature of $70^{\circ} \mathrm{C}$ with a rotation of $100 \mathrm{rpm}$. The oil which has been separated from the solvent is then purified using bentonite with variations of 25, 50 and $75 \%$ by weight of CRBO. Bentonite used is bentonite which has been heated at $105^{\circ} \mathrm{C}$ for two hours.

\subsection{Parameter}

Purified bran oil is measured by parameters yield (\%), water content, acid value, peroxide value, iodine value and fatty acid composition.

\section{Results and Discussion}

\subsection{Percentage of Rice Bran Oil Yield}

Determination of percent yield aims to determine the level of rice bran oil obtained from the extraction of liquid-solid (leaching) at each extraction time variation. The percent yield of bran oil produced on the effect of the extraction time can be seen in Fig. 1. 


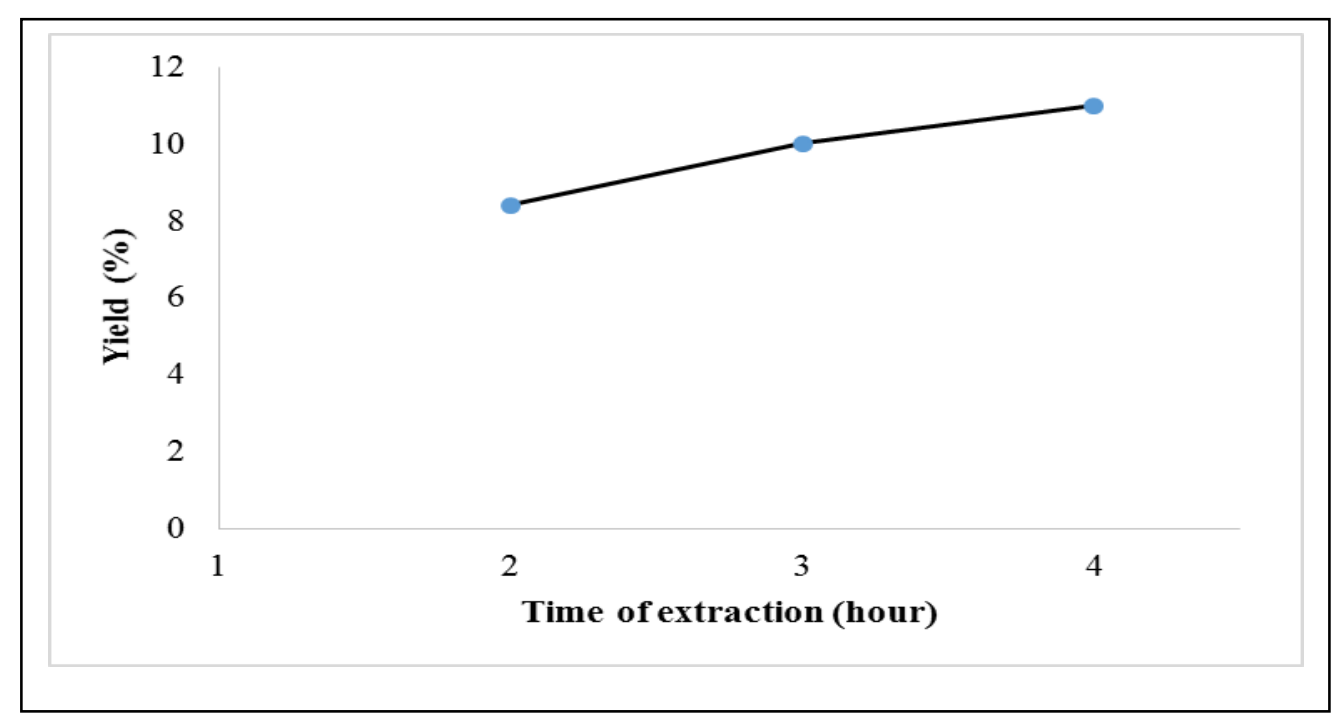

Figure 1. Effect of Extraction Time on\% Yield of Rice Bran Oil

Fig. 1 showed that the longer the extraction time, the greater the yield. The large increase in CRBO yield of about $9 \%$ from the extraction time of 2 hours to 3 hours. But from the extraction time from 3 hours to 4 hours, only $3 \%$. The longer extraction time, oil produced is getting bigger, although the increase is only a few percent [6].

\subsection{The Water Content of Rice Bran Oil}

Analysis of water content is determined by following the analysis standards of SNI 01-35551998 on how to test fat and oil. The water content analysis carried out in duplicate is divided into several criteria of test variables, namely testing on bran oil before refining (sample A) and rice bran oil that has been purified using a ratio of $25 \%$, 30\%, and $35 \%$ weight of bentonite from the volume of oil (samples B, C and D).

Table 1. Effects of Extraction Times and Refining Using Bentonite on Water Content

\begin{tabular}{cccc}
\hline Sample & \multicolumn{3}{c}{$\begin{array}{c}\text { Water content } \\
(\%)\end{array}$} \\
\cline { 2 - 4 } & 2 hr extraction & 3 hr extraction & 4 hr extraction \\
\hline A & 9.6 & 10.5 & 11 \\
B & 9.5 & 9 & 9.3 \\
C & 8.6 & 8.7 & 8.8 \\
D & 8 & 8.5 & 8 \\
\hline
\end{tabular}

Information :

sample A: extraction of rice bran oil (CRBO) without the addition of bentonite sample B: extraction of rice bran oil and refining using $25 \%$ bentonite from CRBO sample C: extraction of rice bran oil and refining using $50 \%$ bentonite from CRBO sample D: extraction of rice bran oil and refining using $75 \%$ bentonite from CRBO 
Table 1 showed that at 2 hour extraction and the use of $25 \%$ bentonite only decreased $1 \%$ water content. However, the use of bentonite 50 and $75 \%$ can reduce the water content of 11 and 20\%. This shows that the greater use of bentonite can reduce the water content of oil.

\subsection{The Results of The Value of Fatty Acids, Iodic Value and Peroxide Value of Rice Bran Oil}

Data on the results of fatty acid values (AV), peroxide values (PV) and iodine values (IV) of rice bran oil can be seen in Table 2 .

Table 2. Results of AV, PV and IV Analysis of Rice Bran Oil at Various Extraction Times

\begin{tabular}{|c|c|c|c|c|c|c|c|c|c|}
\hline Extraction & \multicolumn{3}{|c|}{2 hour } & \multicolumn{3}{|c|}{3 hour } & \multicolumn{3}{|c|}{4 hour } \\
\hline Sample & $\mathrm{AV}$ & P V & I V & AV & P V & I V & AV & P V & I V \\
\hline A & 67 & 21 & 43 & 67 & 21 & 41 & 67 & 21 & 40 \\
\hline B & 67 & 21 & 43.5 & 67 & 21 & 42 & 67 & 21 & 44 \\
\hline $\mathrm{C}$ & 67 & 21 & 45 & 67 & 21 & 45.7 & 67 & 21 & 45 \\
\hline D & 67 & 21 & 47 & 67 & 21 & 46 & 67 & 21 & 46 \\
\hline
\end{tabular}

Table 2 showed that the extraction of 2, 3 and 4 hours did not affect changes in AV and PV even though the adsorption process was carried out. Whereas purification using bentonite influences the increase in IV. The more bentonite is added, will increase the value of iodine. Iodine value indicates the level of unsaturation of fatty acids that make up oil. Unsaturated fatty acids are able to bind iodine and form saturated compounds. The amount of iodine that is bound indicates the number of double bonds of unsaturated fatty acids.

\subsection{The GC-MS Analysis of Rice Bran Oil}

The results of the analysis composition of fatty acids in rice bran oil can be seen in Fig. 2 which shows the chromatogram analysis. On the chromatogram there is a graph containing a peak, that shows the composition and the amount of the constituent samples of rice bran oil. On the graph, the ' $\mathrm{X}$ ' axis indicates retention time or component separation time, while the ' $\mathrm{Y}$ ' axis shows the abundance of certain substances contained in the injected sample. There are 17 types of constituents of rice bran oil samples which are all recorded at the peak in the chromatogram. However, only 5 peaks whose levels are quite high and are the dominant compound in rice bran oil samples. 


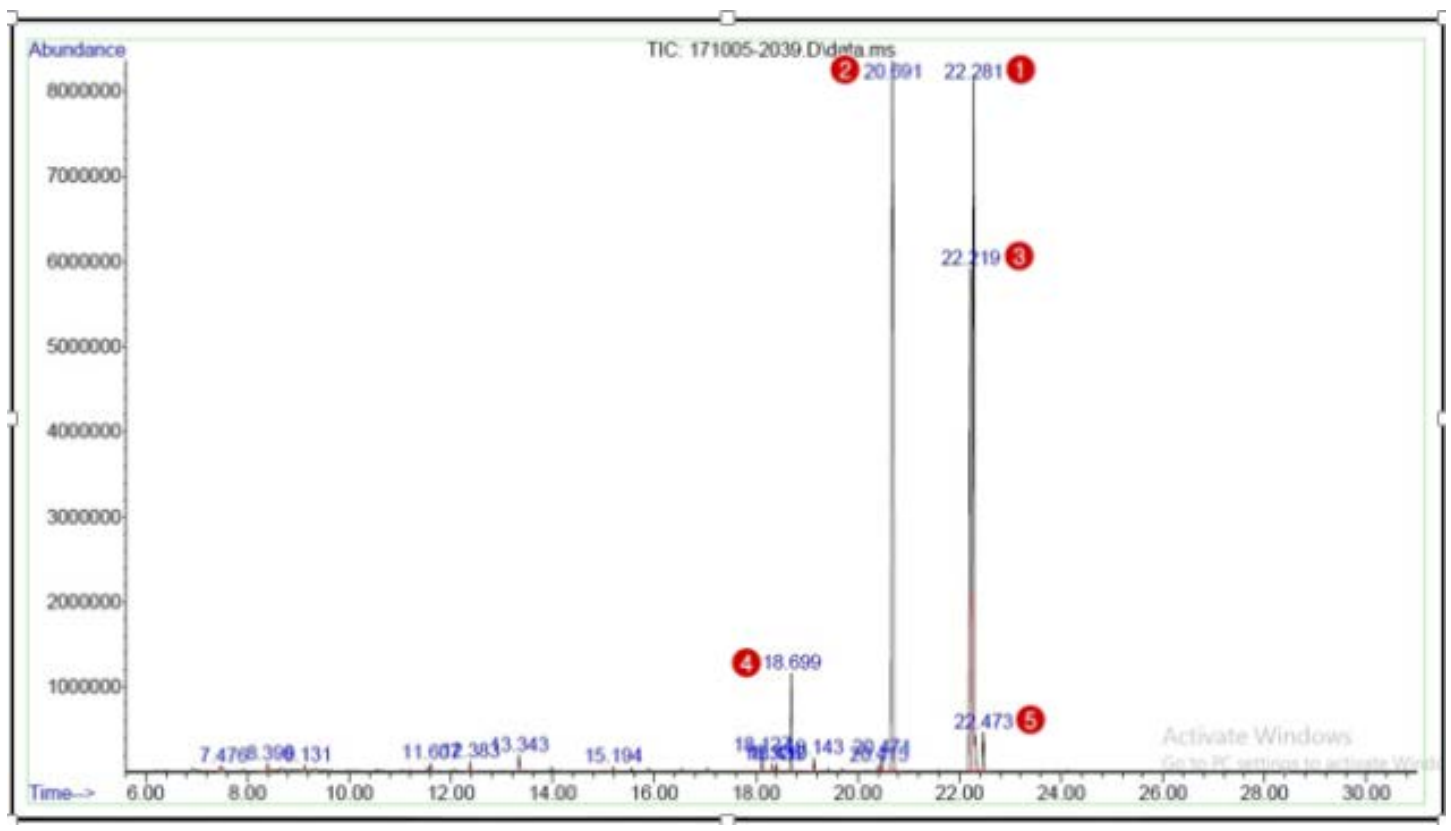

Figure 2. GC-MS Chromatogram of Fatty Acid of Rice Bran Oil

Table 3 showed some of the dominant compounds contained in rice bran oil of researcher conducted by Sri, Hadipernata [5], and Fajriyati [10]. The content of saturated fatty acids and unsaturated fatty acids from rice bran oil is about $24-29.5 \%$ and $68 \%-73 \%$, respectively. The amount of unsaturated fatty acids in rice bran oil is dominated by oleic and linoleic acids which can be used as raw material for medicine.

Table 3 Fatty Acid Data from GCMS Analysis of Rice Bran Oil

\begin{tabular}{cllccc}
\hline No & Fatty acid & $\begin{array}{l}\text { Types of fatty } \\
\text { acids }\end{array}$ & $\begin{array}{c}\text { Sri et al } \\
(\%)\end{array}$ & $\begin{array}{c}\text { Hadipernata et. al } \\
(\%)\end{array}$ & $\begin{array}{c}\text { Fajriyati et al } \\
(\%)\end{array}$ \\
\hline 1 & Oleic acid & unsaturated & 33.5 & 38.4 & 36 \\
2 & Linoleic acid & unsaturated & 32.7 & 34.4 & 35 \\
3 & Palmitic acid & saturated & 25 & 21.5 & 21 \\
4 & Myristic acid & saturated & 3 & 0 & \\
5 & Stearic acid & saturated & 1.5 & 2.9 & 2.7 \\
\hline
\end{tabular}

\section{Conclusions and Future Research}

The optimum conditions in rice bran oil extraction in this study were 4 hours and $75 \%$ bentonite adsorption from CRBO yielded 11\% yield, 8\% water content, AV $67 \mathrm{mg} \mathrm{NaOH} / \mathrm{g}$ sample, PV $21 \mathrm{mgrek} / \mathrm{g}$ sample, IV $21 \mathrm{mg} \mathrm{I} / \mathrm{g}$ sample, and 68\% unsaturated fatty acids and 29.5\% unsaturated fatty acids. Further research on rice bran oil produced will be carried out ozonation to produce trioxolane compounds. 


\section{Acknowledgements}

This research was funded entirely through the Ministry of Research, Technology and Higher Education (RISTEK-Higher Education), Competitive Research Grant No. 225/SP2H/LT/ DRPM/ 2019. Authors would like to thank the Environmental Laboratory - Institut Teknologi Indonesia and Indonesian Institute of Sciences for guidance and research facilities. And thank also for a Nisya Oktarinasiwi and Alfira Novihartuti for collaboration in working on this research.

\section{REFERENCES}

[1] N. R. Almeida, A. Beatriz, A. C. Micheletti, and E. J. de Arruda, "Ozonized vegetable oils and therapeutic properties: A review," Orbital - Electron. J. Chem., vol. 4, no. 4, 2013.

[2] M. Chen, S. H. Choi, N. Kozukue, H. Kim, and M. Friedman, "Growth-Inhibitory E ff ects of Pigmented Rice Bran Extracts and Three Red Bran Fractions against Human Cancer Cells: Relationships with Composition and Antioxidative Activities,” 2012.

[3] Geogel, U., Tasan, Murat., Daglioglu, Orhan, Rice Bran ; Nutritional Components and Health Benefits. Turkey : Namik Kemal University-Agricultural Faculty-Departement of Food Engineering. 2012.

[4] A. J. Henderson et al., "Chemopreventive Properties of Dietary Rice Bran: Current Status and Future Prospects 1, 2,” pp. 643-653, 2012.

[5] M. Hadipernata, "Mengolah Dedak menjadi Minyak (Rice Bran Oil)”, J. Warta Penelitian dan Pengembangan Pertanian, 2007.

[6] Suryati, "Proses Pembuatan Minyak Dedak Padi (Rice Bran Oil) Menggunakan Metode Ekstraksi”, Jurnal Teknologi Kimia Unimal, 2015.

[7] S. Nasir, F.H. Kamila, "Ekstraksi dedak padi menjadi minyak mentah dedak padi (crude rice bran oil) dengan pelarut n-hexan dan ethanol”, Jurnal Teknik Kimia. 2009.

[8] A. Setiawan, Pato, U. \& Hamzah, F., "Pemurnian Minyak Goreng dari Biji Karet Menggunakan Zeolit”, Jurnal Faperta, pp. 1-10, 2016.

[9] T. Azis, L. K. Dewi, Hendra, Optimasi pemucatan minyak mentah dedak padi dengan menggunakan karbon aktif. Jurnal Teknik Kimia, vol. 15, no. 1, pp. 25-30, 2008.

[10] F. Mas, M. Mahendradatta, A. Laga, and Z. Zainal, "Component , Fatty Acid And Mineral Composition Of Rice Bran Oil Extracted By Multistage With Hexane And Ethanol,” vol. 6, no. 11, pp. 63-69, 2017. 